\title{
Competition in Russia's Banking Sector Prior to and After Supervision Policy Enhancement: Conclusions Based on Interest Rate Dispersion and Spread
}

Yulia Ushakova, Bank of Russia ushakovayuv@cbr.ru

Anna Kruglova, University of Washington

Enhancement of the Bank of Russia's supervision policy in 2013 has heightened the relevance of evaluating banking competition as a tool to study the effects of banking sector recovery. We propose simple-tocalculate competition measures based on the dispersion and spread of loan and deposit rates across banks adjusted for the estimated risk of banks' lending policy. Estimation was performed for the period of 2010-2017. We have found no weakening in competition as measured by these indicators. This result has been corroborated by estimating an alternative but more elaborately calculated competition measure - the Boone indicator. We have also found that the period following this policy launch saw a drop in the volatility of corporate and retail lending in both the cluster of banks showing a relatively low level of nonperforming loans and among banks with a relatively high NPL level. This is accompanied by relatively low values of the systemic risk indicator SRISK and gradual recovery of the Z-index, which agrees with banking sector stability improvement.

Keywords: Russia's banking sector, proactive supervision policy, competition measures, banking sector stability

JEL: G28, G21, E43
Citation: Ushakova, Y., Kruglova, A. (2018). Competition in Russia's Banking Sector Prior and After Supervision Policy Enhancement: Conclusions Based on Interest Rate Dispersion and Spread. Russian Journal of Money and Finance, 77(2), pp. 22-50.

doi: $10.31477 /$ rjmf.201802.22

\section{Introduction}

From the start of 2013 to June 1, 2017, the Bank of Russia withdrew 332 licenses from banks grossly in breach of Russian legislation. This policy has resulted in, among other things, a rise in the concentration of Russia's banking sector (Table 1) sometimes viewed as a negative trend. 
Table 1. Asset concentration in Russia's banking sector, $\%$

\begin{tabular}{|l|l|l|l|l|}
\hline 01.01 .2013 & 01.01 .2014 & 01.01 .2015 & 01.01 .2016 & 01.01 .2017
\end{tabular}

\begin{tabular}{lccccc} 
Share in assets of top-5 banks & 50.3 & 52.7 & 53.6 & 54.1 & 55.3 \\
\hline Share in assets of top-20 banks & 69.8 & 71.7 & 75.1 & 75.7 & 78.1 \\
\hline Share in assets of top-50 banks & 81.4 & 82.8 & 85.7 & 87.0 & 88.7 \\
\hline HHI Index (on assets) & 1104 & 1153 & 1156 & 1162 & 1221 \\
\hline
\end{tabular}

Source: Bank of Russia, authors' estimates

The banking sector's rising concentration has brought up the question of how strong is the competition in the banking sector and what negative effects competition weakening in this area could bring about on society. We note that whether competition is desirable in the banking sector is not a straightforward issue, see, e.g., Vives (2016). ${ }^{1}$ This issue, however, will not be considered as part of this paper.

The aim of this study is to analyze the performance of competition indicators prior to and after the launch of proactive supervision policy by the Bank of Russia, i.e., in the 2010-2017 time span. For this purpose, we choose competition indicators based on the dispersion and spread of loan and deposit rates across banks adjusted for banks' estimated lending policy risk. These indicators are fairly simple to estimate and easily interpreted. We complement this exercise with the estimates of a more complex competition measure - the Boone indicator. Computing of competition indicators prior to and after the launch of proactive supervision policy by the Bank of Russia enables us to test its dynamics for structural breaks. Presence of such breaks can indicate significant effect of the proactive supervision policy of the Bank of Russia on the competition dynamics in the sector.

An incentive to do this research was provided by the result which Ponomarenko and Sinyakov (2018) obtained as part of an agent-based model of the banking sector calibrated for Russia, under which competition temporarily weakens in the banking sector after proactive supervision policy is launched.

In addition, we examine changes in the Russian banking sector's stability, which reflect the sector's exposure to credit and other risk types, such as interest and liquidity risks. ${ }^{2}$

We have found that various competition indicators do not support the hypothesis of competition weakening in the Russian banking sector in the period

\footnotetext{
${ }^{1}$ The conventional wisdom is that competition can indeed have an adverse effect on the financial sector's stability - the competition-fragility hypothesis (Smith,1984; Matutes and Vives, 2000; TurkAriss, 2010; Fungacova, 2013). By contrast, Boyd and De Nicolo (2005) show that banks' stronger market power (weaker competition) sets off the risk accumulation mechanism - the competitionstability hypothesis. In empirical terms, the correlation between competition and stability was found in Uhde and Heimeshoff (2009); Schaeck et al. (2014). The third group of studies suggest a nonlinear relationship between competition and banking sector stability (Martinez-Miera and Repulo, 2010; Uhde and Heimeshoff, 2013). It is noteworthy that the latest empirical studies look into individual and systemic risks (Leroy and Lucotte, 2017).

2 The volatility of loan portfolio growth rate, the Z-index for stability under Roy's methodology along with the systemic risk indicator SRISK, were used as stability measures.
} 
following the launch of proactive supervision policy by the Bank of Russia. On the contrary, some competition measures suggest that competition may have gradually strengthened in the banking sector's main segments. But nor can we assert that competition strengthening is owed to proactive supervision policy pursued by the Bank of Russia. The significance of this factor does not prove robust to the methods of competition assessment.

We have also found that the period following this policy launch saw a drop in the volatility of corporate and retail lending in both the cluster of banks showing a relatively low level of nonperforming loans and among banks with a relatively high level of bad debts. This is accompanied by relatively low values of the systemic risk indicator SRISK and gradual recovery of the Z-indicator, reflecting the sector's "immunity" to risks. The latter agrees with a rise in the stability of the banking sector's performance.

This paper is structured as follows. The second section provides a review of competition measures. The third section describes the methods of estimating competition measures and testing them for structural breaks. The fourth section presents estimation and testing results. The fifth section analyzes the measures of banking sector stability. The last section sums up the main conclusions.

\section{Literature review}

Competition is usually understood as banks vying for new and/or keeping the existing customers. Competition is essentially an unobservable quantity. The literature suggests several approaches to its assessment.

- Measures of banking sector concentration, in particular, the HerfindahlHirschman index and its modifications. According to the World Bank research (Beck, 2008), conventional concentration measures only reflect the market structure and are not clearly related to competition. For example, a rise in banking sector concentration may be concurrent with competition strengthening as part of banking sector consolidation (Beck, 2008). Moreover, concentration measures do not capture competition from potential new market players and therefore fail to take account of the actual strength of competition in the sector (BIS, 2018). Classens and Laeven (2004), for instance, obtained no evidence that concentration measures are negatively related to competition. What is more, there is still no consensus in the literature on whether market structure indicators constitute the determinants of banks' behavior (the structure-behaviorresult paradigm, see Mason, 1939), or, conversely, the market structure is a consequence of how efficiently banks operate (the efficient structure paradigm (Demsetz, 1973). Thus structural indicators, i.e. measures of concentration, alone provide no insight into how strong competition in the banking sector is.

- Straightforward competition measures based on price dispersion across sellers (see Orlov, 2011; Lach, 2002; Salop and Stiglitz, 1977). Competition 
strengthening implies that price dispersion (measured by standard deviation and difference in distribution percentiles) declines.

- Straightforward indicators similar to the Lerner index (Lerner, 1934). The Lerner index (LI) measures the degree of market power as a ratio of a monopoly markup to the price of a product:

$$
L I_{i t}=\frac{P(Q)_{i t}-M C_{i t}}{P(Q)_{i t}}
$$

This index takes values from 0 to 1 , and the higher the value, the higher a bank's market power. In this context, it is important to define a bank's output. In empirical studies, a bank's assets or its total loans are usually regarded as its output.

An analog of the Lerner index is marginal profit (markup) adjusted for credit policy risk. A bank's markup is here defined as loan rates less deposit rates, which is also termed an interest rate spread. Indeed, a bank's marginal profit is made up of its profit on the assets side and that on the liabilities side. Profit on the assets side equals the difference between the loan price (a rate on a loan) and the marginal lending cost, or the cost of funding loans (the key interest rate or an interbank market rate for loans of relevant maturities). Marginal profit on the liabilities side equals the difference between the key rate (the interbank market rate) and marginal costs in this case, i.e., the rate on deposits of relevant maturities. The Lerner index thus defined is widely used as a measure of competition (see a review in Vives, 2016, pp. 88-89; Carbo et al., 2009; Fernández de Guevara and Maudos, 2004; Fernández de Guevara et al., 2007).

- The Boone indicator (Boone, 2008). The Boone indicator ( $\beta$ ) estimates to what extent efficiency improvement (cost reduction) can increase a bank's market power (market share) $\left(s_{i t}\right)$ or its profitability ratio - ROA $\left(\pi_{i t}\right)$ :

$$
\begin{aligned}
& \ln \pi_{i t}=\alpha+\beta \ln M C_{i t}+\varepsilon_{i t} \\
& \ln s_{i t}=\alpha+\beta \ln M C_{i t}+\varepsilon_{i t}
\end{aligned}
$$

That said, the estimation of marginal costs takes into account not only interest costs, but also operating costs. If the effect $(\beta)$ is negative, then more efficient banks are able to improve their market positions or business profitability, hence the system is more competitive. Note that the specific values of the Boone indicator do not matter. What is important is that the effect should be negative, while in analyzing a competition trend, a conclusion that competition is on the rise can be drawn if the index value does not increase. To estimate this indicator, fairly complicated calculations are required, so it is not illustrative enough in this respect.

- H-statistic (Panzar and Rosse, 1987). The idea of the Panzar - Rosse $\mathrm{H}$-statistic is to measure the impact of change in input prices on a bank's 
revenue. For this purpose, first, econometric estimation of elasticities of banks' interest (or total) revenue (Rev) with respect to prices for three inputs $(w)$ - the cost of funds, the cost of labor and other expenses of banks' interest is undertaken. The elasticities thus estimated are then summed to obtain H-statistic (H).

$$
\begin{gathered}
\ln \left(\operatorname{Rev}_{i t}\right)=\alpha_{i}+\sum_{k} \beta_{k} \ln w_{i t}^{k}+\sum_{l} \gamma_{l} Z_{i t}^{l}+\varepsilon_{i t} \\
H=\sum_{k} \beta_{k}
\end{gathered}
$$

If the obtained $\mathrm{H}$-statistic is non-positive, the market under consideration is deemed to be monopolistic. In the case of the monopolistic competition model, $\mathrm{H}$-statistic is supposed to be within the range from 0 to 1 , while in the case of perfect competition it equals 1. But, as shown in Shaffer (1982), $\mathrm{H}$-statistic can only be correctly determined for a banking system which is in a long-run equilibrium. Also, to draw a conclusion about the degree of competition, the conditions of the Cobb-Douglas constant elasticity of demand and bank technology in the Cobb-Douglas form should be satisfied.

We note that the unobservable nature of competition as a concept gives rise to a significant variety of indicators, which measure it. Also, as quality criteria of competition measures have yet to be found, one cannot draw a conclusion that some of specific competition measures are correct and some are not. As a result, most studies tend to present the performance of several competition indicators at once, see, e.g., BIS (2018), Mamonov (2016). To provide such a quality criterion, a certain reference could be introduced, that of an economy with a perfect competition and one with a perfect monopoly. Then, out of all the indicators presented one could choose which of them are accurate competition measures and which are poor simply based on their ability to predict (forecast) the level of competition. We are not aware of any studies drawing such a comparison for the indicators presented above. The difficulty is that this should be an empirical reference rather than a model. As any research experiments in a social science such as economics, empirical references involve a well-known fundamental problem: controlled experiments are very hard to implement. Meanwhile comparisons in model economies cannot provide a criterion of truth, as an alternative theoretical model can always be constructed in which accurate competition measures would prove to be poor while poor ones would come out adequate. It is impossible to recognize which of the models is accurate without carrying out an experiment, hence the comparison of models cannot act as a criterion of scientific truth, nor can any claims that certain competition indicators are "standard". This study does not seek to compare measures of competition based on any criteria, and, given what was said above, this can hardly be achieved.

\footnotetext{
${ }^{3}$ A good example of how much one can be mistaken in relying on "standard results in the literature" is provided by Reinhart and Rogoff's paper estimating an equilibrium debt level. This study was very popular and much cited as "standard" until major errors were found in the authors' calculations.
} 
In conclusion, we will refer to some of empirical studies on Russia's banking sector. Drobyshevsky and Pashchenko (2006) showed that there are segments with both strong and weak competition in the Russian banking services market, with the largest group of banks operating in the weak competition segment. However, the 2001-2007 and 2010-2013 periods, i.e., pre- and postcrisis ones, saw a slight rise in competition (Fungacova et al., 2010; Mamonov, 2016). By contrast, during the 2008-2009 crisis, competition weakening was seen (Mamonov, 2016). As regards the level of competition, contrary to the stereotype notions of the Russian market, in the 2000s it saw a degree of competition roughly equal to that in developed countries (Fungacova et al., 2010).

We note that studies by Russian researchers use predominantly nonstructural methods of competition assessment. For instance, Drobyshevsky and Pashchenko (2006) carry out estimation using the Bresnahan and Barros - Modesto model. Anisimov and Vernikov (2011) constructed H-statistic indicators. Mamonov (2016) uses a complex approach, estimating, in addition to the Herfindahl - Hirschman index, $\mathrm{H}$-statistic, the Boone indicator, and the Lerner index.

In this study we opted for using the most straightforward and intuitively clear competition indicators, specifically, those measuring the dispersion and spread of loan and deposit rates adjusted for estimated banks' lending policy risk, with roughly homogenous groups of banking products distinguished. In addition, the performance of an alternative competition measure - the Boone indicator, was estimated. The estimation methodology is described in the next section.

\section{Dataset and methodology of the study}

\subsection{Dataset and period of the study}

The empirical basis of the study was provided by monthly reporting forms № 128-129 containing data on the weighted average interest rate and amounts of new deposits and loans, monthly reporting form № 101 presenting data on banks' key balance sheet indicators, as well as quarterly reporting form № 102 comprising data on banks' income and expenses along with the structure thereof.

The period under study is January 2010 - March 2017. Note that we regard October 2013 as the time when the new banking sector recovery policy was launched. Note also that there is no clear-cut launching date for this policy. It is generally assumed that proactive supervision policy was started when Elvira Nabiullina was appointed the Governor of the Bank of Russia in June 2013 and Federal Law № 86-FZ of 10.07.2002 On the Central Bank of the Russian Federation was amended to include a chapter dealing with the financial market development and securing the stability of its operation in late June 2013. The awareness of a systemic nature of policy pursued came, in our view, somewhat later, after a highprofile license withdrawal, in September 2013, from Pushkino Bank, which at that time set an anti-record of payments received from the Deposit Insurance Agency, and, in November 2013, from Master-Bank belonging to the top-50 group. 


\subsection{Measuring competition}

According to the classical economic theory (Robinson, 1933), in a perfect competition market, there exists a standardized product and many similar players that do not influence its price. The price is therefore set by the market, it is similar for all the players and only includes costs. In a monopolistic market, one player charges a price, which, in addition to the costs, includes a monopolistic premium (Lerner, 1934). Therefore, presence in the market of similar players and different prices for a standardized product can be interpreted as an imperfect competition. Under this approach, the degree of price dispersion for similar products among similar players is a proxy for the level of competition, and, consequently, a rise in competition is accompanied by a decline in price dispersion (see also Orlov, 2011, and Lach, 2002).

As applied to the banking sector, this means that competition strengthening will be accompanied by rate dispersion narrowing. For instance, on the liabilities side, banks compete for depositors, seeking to attract them with more lucrative interest rates, thereby making deposit rates move upwards. Meanwhile a rise in the maximum interest rate turns out to be limited because there are other sources of liabilities (it is, for example, limited by the interest rate on repo transactions with the Bank of Russia.). As a result, the toughening of competition on the liabilities side causes rate dispersion to narrow. Likewise, on the assets side, banks striving to get hold of borrowers showing an acceptable level of risk will be eager to reduce rates for them. But the cuts of the minimum rate will be limited by, among other things, the level of income from alternative products (for example, by the rate of deposit auctions at the Bank of Russia). As a result, competition strengthening brings about the narrowing of loan rate dispersion.

Following this logic, we used two indicators of rate dispersion as a competition measure: the maximum rate less the minimum on $e^{4}$ and the standard deviation of rates for each of the main business lines of a bank engaged in household and corporate deposit-taking and issuing corporate and retail loans.

To secure greater homogeneity of products inside each of the abovementioned business areas, competition trends were analyzed for products of similar maturities. We chose products making up the largest share of the banking system's deposits and loans. Note that competition was analyzed using only data on ruble-denominated deposits and loans. Rates on foreign currency-denominated deposit and loans may, in our view, inaccurately reflect competition performance in these segments due to a variety of macroprudential policy measures and geopolitical factors. As a result, the following instruments were chosen:

- ruble-denominated household deposits with maturities of 91 to 180 days, 181 days to 1 year, from 1 year to 3 years (75\% of the banking system's household deposits as of 01.04.2017);

\footnotetext{
${ }^{4}$ The rate corresponding to the $95^{\text {th }}$ percentile of rate distribution was used as a maximum rate, the rate from the $5^{\text {th }}$ percentile was deemed to be the minimum rate. The rationale for this is the need to trim reporting "errors" which were in our view concentrated in the distribution tails.
} 
- ruble-denominated corporate deposits for terms of 31 to 90 days and over 3 years $(41 \%$ of the banking system's corporate deposits as of 01.04.2017);

- ruble-denominated household loans with maturities of 1 to 3 years and over 3 years ( $81 \%$ of the banking system's retail loans as of 01.04 .2017 );

- ruble-denominated corporate loans with maturities of 1 to 3 years and over 3 years $(76 \%$ of the banking system's corporate loans as of 0.1.04.2017).

According to the Arbitrage Pricing Theory by S. Ross (Ross, 1976), the rate reflects a risk-free return and combination of risks assessed by the market: the individual (specific) risk, the systematic risk and other types of risks. Therefore, if similar banks ${ }^{5}$ with equivalent assets operate in a competitive market, their prices will tend to converge. For the prices-rates examined to become equivalent, we eliminated bank-specific and systematic risks from them.

We assume that the nature of competition in the household segment is different from that in the corporate banking segment. For instance, in choosing a bank, individuals look more to the deposit rate offered by the bank. ${ }^{6}$ This assumption means that individuals have no loyalty towards a specific bank based on their past experience, and also that the so-called national champions enjoy no privileges in this respect (Vernikov, 2013). If, out of all available options, individuals choose a bank offering the highest rate on deposits and charging the lowest rate on loans, this implies the lack of geographical differentiation of banking services markets (a resident of Kaliningrad in Russia's westernmost part would not go to Irkutsk in Siberia to open a deposit account at a higher rate).

Corporate customers make their choice based on both the level of the interest rate and the size of the bank itself. It would be logical to assume that in this case the size effect matters a lot in choosing a bank (small banks are unable to finance large investment projects). Also, in choosing a bank, corporate customers may seek to minimize the risk of a loss of funds, which is to a certain extent a function of a bank's size. Therefore, in analyzing competition trends in the corporate banking segment we normalized the rates by the size of banks' loan portfolios.

Thus we analyzed the performance of dispersion of rates adjusted for the systematic and specific risks in the retail segment. To analyze the performance of rate dispersion in the corporate segment, we adjusted the rates for the systematic and specific risks as well as bank size. ${ }^{7}$ The narrowing of rate dispersion was interpreted as competition strengthening in this banking segment.

Another indicator we used was the rate spread. To estimate the difference in the rate spreads, we first determined the spread between loan and deposit rates adjusted for risk, bank size (the corporate segment), and macroeconomic

\footnotetext{
${ }^{5}$ Ones with similar risk profiles.

${ }^{6}$ Thanks to, among other things, the deposit insurance program in place.

${ }^{7}$ Bank size - the average size of bank assets in the last 12 months normalized by inflation for yearto-year comparisons.
} 
factors for each bank at each moment in time. Then we determined the median rate spread for the top-50 banks for each period and the median rate spread for the 150 smallest banks by assets. Then we subtracted the median rate spread for the 150 smallest banks from that for the largest banks to obtain the difference of rate spreads between the large and small banks.

The performance of the indicator obtained provides an insight into how profit is redistributed among banks over time because the rate spread reflects a bank's monopoly power - the difference between the marginal benefit and marginal cost (see Vives, 2016, pp. 88-89). Moreover, when competition is weak, redistribution from small to large banks occurs, which is reflected in a spread increase at the largest banks. And, conversely, as competition strengthens, the difference in large and small banks' spreads between risk- and bank size-adjusted loan and deposit rates levels off.

\subsection{Testing for a structural break}

The performance of each competition indicator was tested for the evidence of a structural break during the period concerned. If found, it may suggest that the enhancement of supervision policy by the Bank of Russia could have had a significant effect on the dynamics of competition processes in the sector.

As the structural breakpoint is unknown, we used the Andrews test for a structural break (Andrews, 1993). Next, the stationarity of the competition indicator performance until the identified structural breakpoint was determined using the unit root tests: ADF, PP (Fuller, 1996; Phillips and Perron, 1998). If the unit root hypothesis was rejected, i.e., the initial series was qualified as stationary, the conclusion about a structural break in the competition indicator performance was accepted based on the Andrews test results obtained in the first step. If the unit root hypothesis was not rejected, i.e., the series was nonstationary before the identified break, then, to identify the structural break date, we converted the competition indicator into the stationary time series and performed the Andrews test or carried out the unit root test with structural breaks.

Apart from the presence of the structural break, we examined factors which could have brought it out. For this purpose, we regressed competition indicator performance on oil price movements and/or the Bank of Russia policy ${ }^{8}$ and performed the Andrews test on regression residuals. If the Andrews test identified a structural break in the initial series, but no longer identified it after oil price movements and/or the Bank of Russia policy were controlled for, we concluded that this factor could have influenced the presence of a break in the competition indicator performance.

\footnotetext{
${ }^{8}$ Dummy variable for the period from October 2013 onwards.
} 


\section{Empirical results}

\subsection{Straightforward measures of competition in the proximity of supervision policy enhancement}

\subsubsection{Indicators of rate dispersion}

The rate dispersion measure we used was the scatter of rates adjusted for systematic and specific risks. In this case, we proxied the bank-specific risk with the share of nonperforming loans in a bank's loan portfolio, using the performance of Russia's five-year $\mathrm{CDS}^{9}$ as a proxy for systematic risk. The systematic and specific risks were factored in by normalizing the rate adjusted for systematic risk by the specific risk:

$$
\text { rate }^{*}=\frac{\text { rate }- \text { CDS }}{(\text { npl })}
$$

It is noteworthy that one comes across instances in banks' reporting where a zero or very close to zero weighted average interest rate on new deposits taken in the last month was reported (with nonzero deposits taken). This "paradox" was observed prior to May 2016, when licenses were withdrawn from most of such banks. There is no way of finding out whether these numbers are misprints (and correcting them). Still, we assume that such "mistakes" are concentrated in the tails of rate distribution. Because of it, we focused our analysis on the changes in the dispersion of rates adjusted for the specific and systematic risks and corresponding to $5 \%$ and $95 \%$ of distribution in each month of the period under study.

In the period concerned, changes in competition as measured by the magnitude of rate dispersion indicated its possible rise in the segments of household deposits (Figure 1) and household loans (Figure 2). We note that a reduction in the rate dispersion proved to be unrelated to the strengthening of Sberbank's market power, as its market share was not expanding in that period. At the same time, the competition indicator performance in the segment of over-3-year corporate loans suggests possible competition weakening in the sector, which became evident after the second half of 2014 (Figure 3).

In the period following the launch of banking sector recovery policy, a significant ${ }^{10}$ break in the performance of the indicator of competition measured by the scale of rate dispersion was only seen in the segments of 1-3-year household deposits (Figure 27, Appendix 1), over-3-year household loans (Figure 29, Appendix 1) and over-3-year corporate loans (Figure 31, Appendix 1). These segments of loan/deposit operations are of relatively large importance to the banking system. As of 01.04.2017, household deposits for terms of 1 to 3 years accounted for around $36 \%$ of all household deposits and just over $11 \%$ of total banking assets; over-3-year household loans represented $72 \%$ of household loans and $14 \%$ of the banking system's assets, the share of over-3year corporate loans was $48 \%$ in total corporate loans and $17 \%$ in total assets.

\footnotetext{
${ }^{9}$ Russia CDS USD SR 5 Y D14 Corp.

${ }^{10}$ The test detects a structural break in August 2015 (p-value $=0.0000$ ) for $1-3$-year household deposits, a structural break in July 2015 ( $\mathrm{p}$-value $=0.0000$ ) for over-3-year household loans, and a structural break in December 2014 (p-value $=0.000$ ) for over-3-year corporate loans.
} 
Figure 1. Rate dispersion* for 1-3-year household deposits, p.p.

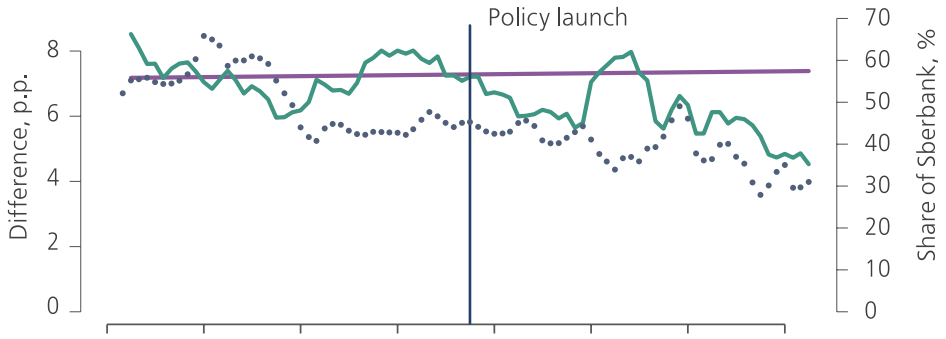

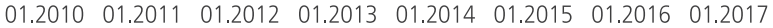

_ Trend before policy launch

...... Sberbank's share Rate dispersion

Figure 2. Rate dispersion* for over-3-year household loans, p.p.

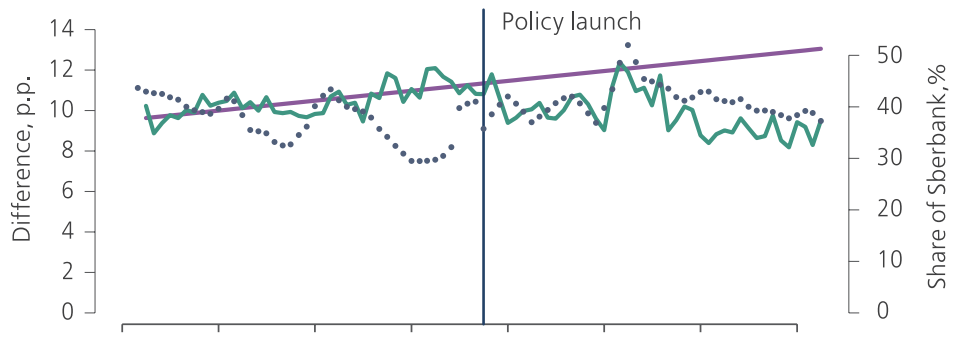

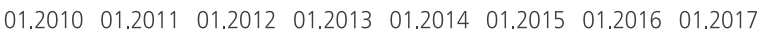

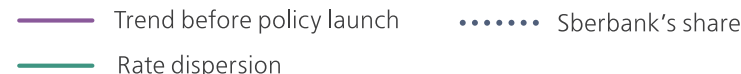

Figure 3. Rate dispersion** for over-3-year corporate loans, p.p.

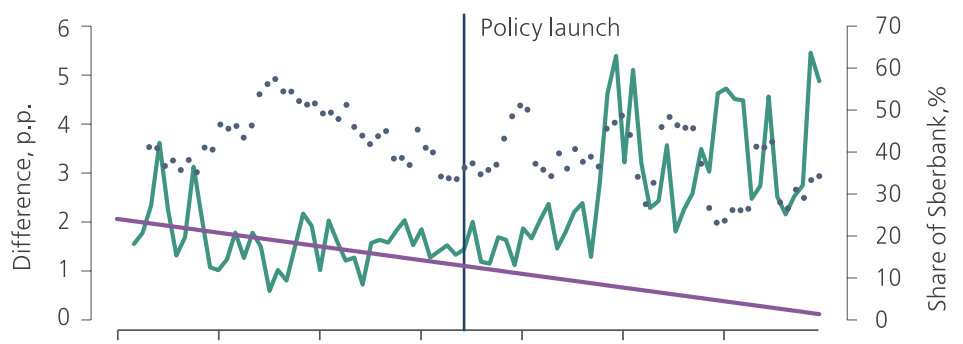

$\begin{array}{lllllll}05.2010 & 05.2011 & 05.2012 & 05.2013 & 05.2014 & 05.2015 & 05.2016\end{array}$

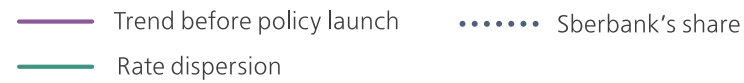

* Dispersion of rates, adjusted for systematic and specific risks.

** Dispersion of rates adjusted for systematic and specific risks and bank size.

Source: authors' estimates 
Further analysis showed that the structural break was in all the cases apparently owed to other (primarily macroeconomic) factors rather than to banking sector recovery policy pursued by the Bank of Russia. For instance, the break in the rate dispersion performance for 1-3-year household deposits becomes insignificant after controlling for the impact of the oil price movements (Figure 27, Figure 28, Appendix 1), just as the break in over-3-year corporate loans detected in December 2014 does (Figure 31, Figure 32, Appendix 1). At the same time, the break in the performance of rates on longer-than-three-year household loans remains significant after controlling for both the impact of banking sector recovery policy (Figure 29, Figure 30, Appendix 1).

See the performance of rate dispersion for other instruments along with formal tests for the significance of the break in Appendix 2.

\subsubsection{Robustness of conclusions to the sample}

We also tested our findings concerning the structural break in the performance of indicators competition measured by rate dispersion, against an alternative sample,

Figure 4. Rate dispersion* for 1-3-year retail deposits across regional banks, p.p.

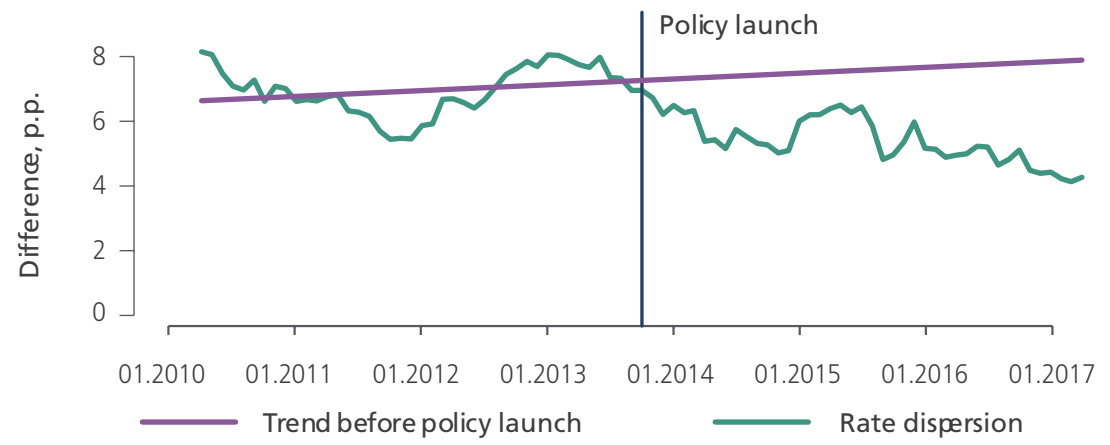

Figure 5. Rate dispersion* for over-3-year retail loans across regional banks, p.p.

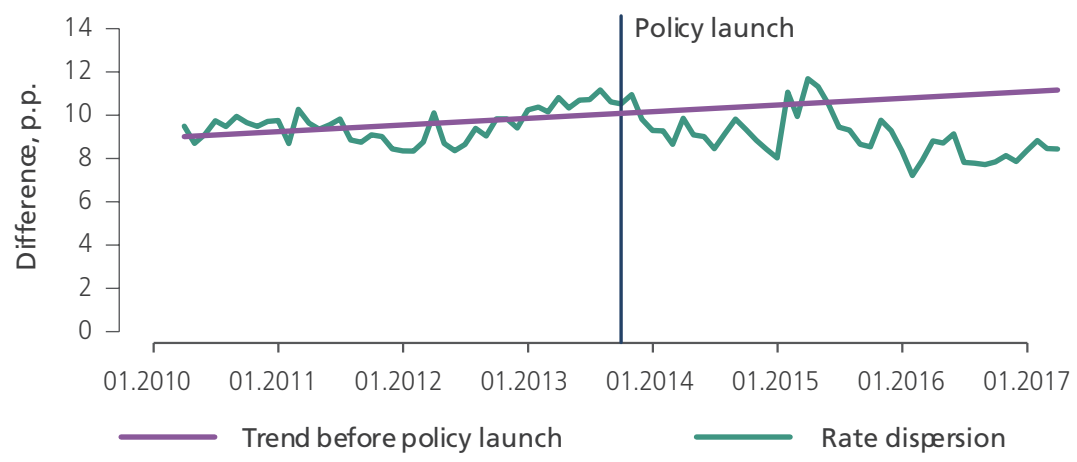

* Dispersion of rates adjusted for systematic and specific risks and bank size.

Source: authors' estimates 
Figure 6. Rate dispersion* for over-3-year corporate loans across regional banks, p.p.

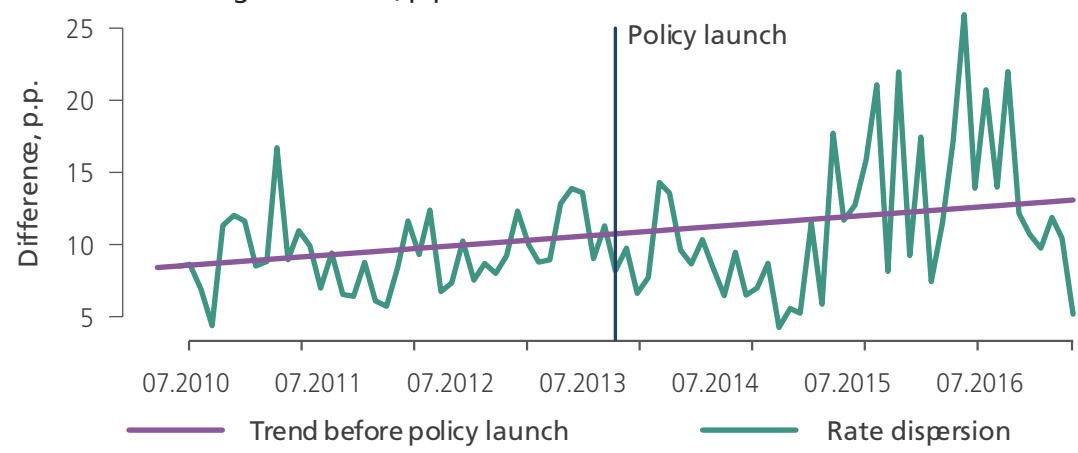

${ }^{*}$ Dispersion of rates adjusted for systematic and specific risks and bank size.

Source: authors' estimates

that of private regional banks, ${ }^{11}$ and obtained similar results. In the period under study, competition measured by the magnitude of rate dispersion showed a similar trend in a subsample of private regional banks in the segment of three-year retail loans and retail deposits for terms of 1 to 3 years (Figure 4, Figure 5). However, rate dispersion in the segment of corporate loans showed no rise at the end of the period in question (Figure 6).

Tests for a structural break in the competition indicator performance on subsample of private regional banks identified a break in about the same months ${ }^{12}$ as in the full sample for the retail lending segment. Also, in all the cases, the structural break proved to be due to macroeconomic factors rather than to banking sector recovery policy pursued by the Bank of Russia (Appendix 3).

\subsubsection{Robustness of results to the methods of adjustment for risk, bank size, and economic factors}

We have performed an alternative interest rate adjustment. For this purpose, we regressed the interest rates on the amount of nonperforming loans and that of bank assets (for the corporate segment) and fixed time effects. In this case, we assumed that banks with a riskier policy will pay a higher rate on deposits. ${ }^{13}$ As a result, we obtained interest rates on loans and deposits adjusted for risk, bank size and macroeconomic conditions (as residuals of the regression presented). At each

\footnotetext{
${ }^{11}$ Regional banks are deemed to be banks with no government or foreign controlling interest in them, as well as banks registered in regions other than the Moscow region (Moscow city and the Moscow Oblast). For a bank to be regarded as regional, all of the above conditions need to be satisfied. In the period under study, the number of regional banks dwindled from 469 to 246.

12 The Andrews rolling test detects a structural break in September 2015 ( $p$-value $=0.0000$ ) for $1-3$ year household deposits, a structural break for in April 2015 ( $\mathrm{p}$-value $=0.0000$ ) for over-3-year household loans and a structural break in January 2015 (p-value $=0.000$ ) for over-3-year corporate loans.

13 This assumption proved accurate for the retail segment and corporate loans (the positive effect of the level of nonperforming loans on the size of loan/deposit rates) but inaccurate for corporate deposits.
} 
moment in time, a rate dispersion magnitude was calculated for them similar to the indicator of rate dispersion in Section 4.1.1:

$$
\text { rate dispersion }{ }_{t}=\text { rate }_{t}^{95 \%}-\text { rate }_{t}^{5 \%}
$$

In calculating this indicator, we decided against further splitting the segments of banking services into maturities, confining retail loans to those with maturities of up to 3 years. Thereby we excluded the mortgage loan portfolio from analysis, as this lending type involves much lower risks. Hence we are now considering just four segments of banking services: household deposits, corporate deposits, household loans and corporate loans.

\section{Corporate loans:}

Rate dispersion measured as described above, tends to decline over the period concerned (Figure 7). The overall downward trend shows a spike in 2015, when there was a surge in the dispersion of rates on corporate loans, possibly due to macroeconomic and financial shocks which the fixed time effects failed to fully account for. As a result, rate dispersion only reached the 2013-2014 level in 2017, absorbing the 2015 spike. Overall, the rate dispersion pattern is in line with the gradual competition strengthening in this banking services segment, which may have taken place even before the Bank of Russia had launched its proactive banking supervision policy.

A test for a structural break in the time series of rate dispersion for corporate loans (detrended and adjusted for the volatility surge in early 2015) detected it in December $2014(\operatorname{supF}=25.92, \mathrm{p}$-value $=0.0000)($ Figure 39, Appendix 4). The structural break in the rate dispersion performance continues to be identified in the same period after the strengthening of banking sector supervision policy by the Bank of Russia was controlled for.

Figure 7. Rate dispersion for corporate loans, p.p.

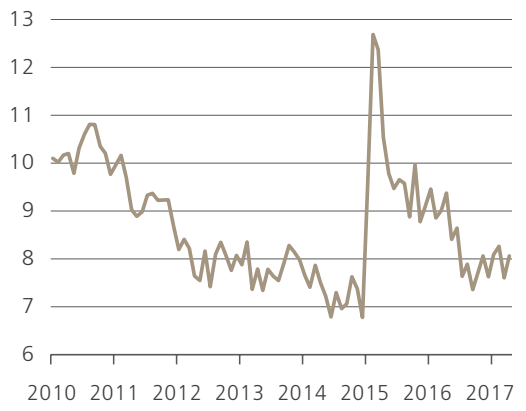

Source: authors' estimates
Figure 8. Rate dispersion for corporate deposits, p.p.

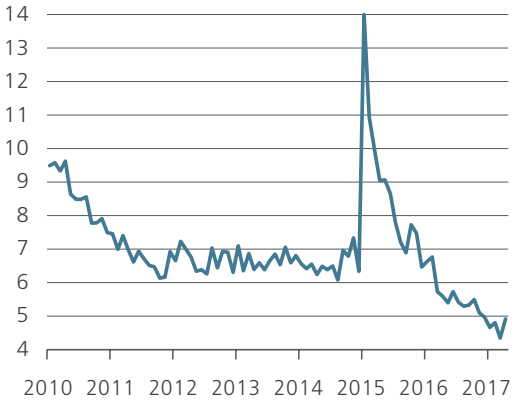


Figure 9. Rate dispersion

for retail loans, p.p.

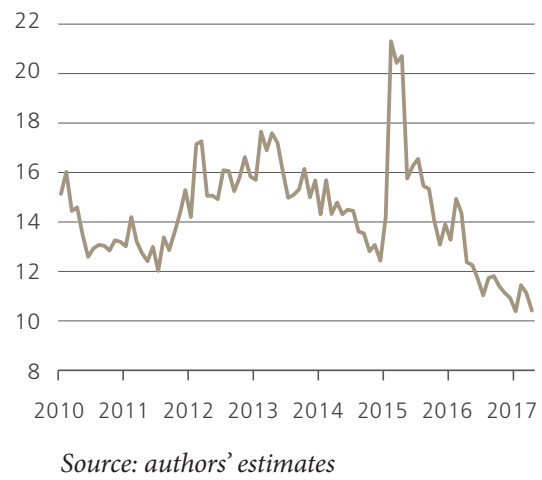

Figure 10. Rate dispersion for retail deposits, p.p.

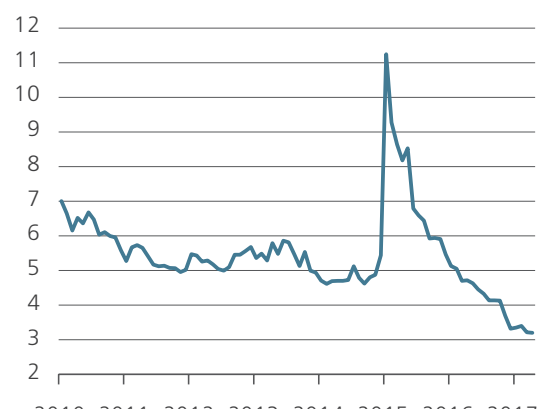

20102011201220132014201520162017

\section{Corporate deposits:}

The dispersion of rates on corporate deposits tends to decline over the period under study. The beginning of 2015 also saw a surge in rate dispersion but this petered out at the end of the year. Moreover, the trend towards rate dispersion decline resumed and increased in 2016 (Figure 8).

A test for a structural break in the time series of rate dispersion for corporate loans (detrended and adjusted for a volatility surge in early 2015) also identified it in January 2016 ( supF $=9.22$, p-value $=0.038$ ). The same test performed after controlling for the impact of the Bank of Russia's proactive supervision policy no longer identifies a break in rate dispersion over the period concerned (Figure 40, Appendix 4). This may evidence a significant impact of banking sector recovery policy on competition strengthening in this segment.

\section{Retail loans:}

The pattern of rate dispersion for retail loans shows a relatively stable level of the competition indicator in this segment in 2010-2014 and possible competition indicator increase at the end of the 2015-2017 period (Figure 9).

A test for a structural break in the rate dispersion series (after taking first differences and controlling for the impact of a surge in rate dispersion in early 2015) detected it in December 2014 ( $\operatorname{supF}=15.23$, p-value $=0.002)$. However, as the launch of proactive supervision policy by the Bank of Russia was controlled for, it failed to fully account for the structural break in that year. After this factor was controlled for in 2016, a test for a structural break showed a break remaining in the series in January 2016 (Figure 41, Appendix 4).

\section{Retail deposits:}

Estimation shows a relatively constant level of the competition indicator in this segment throughout 2010-2013. Similarly to the banking segments described above, the rate dispersion increased dramatically in late 2014 - early 2015, which may have been caused by negative macroeconomic and financial shocks. 
Nevertheless, this rate dispersion surge leveled out quite rapidly, and over recent years the rate dispersion pattern has shown a steady decline, which may suggest competition intensification in this segment (Figure 10).

A test for a structural break suggests a break in the rate dispersion series (detrended and adjusted for a volatility spike in early 2015) in 2016 (supF = 11.73, p-value $=0.012$ ) (Figure 42, Appendix 4). The Bank of Russia's proactive supervision policy seems to have had no significant effect on competition performance, since a test for a structural break after controlling for the relevant variable continued evidencing a break in the rate dispersion series in February 2016.

\subsubsection{Standard deviation}

The standard deviation can also act as an indicator of rate dispersion. To estimate standard deviation, we used rates for each of the main banking segments obtained in the previous step and computed their standard deviation at each moment in time (Figures $11-14$ ). We note the similarity of dynamics of rates with that of rate dispersion obtained in Section 4.1.3. in the main segments

Figure 11. Standard deviation of rates on retail loans, p.p.

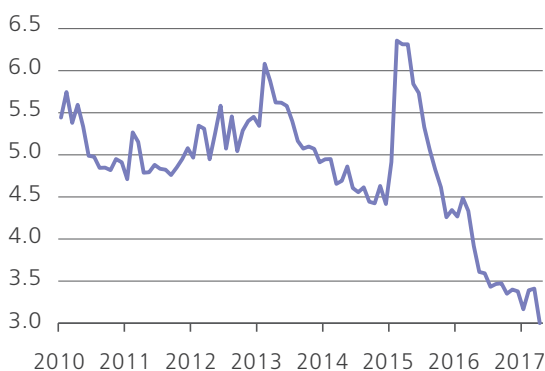

Figure 13. Standard deviation of rates on corporate deposits, p.p.

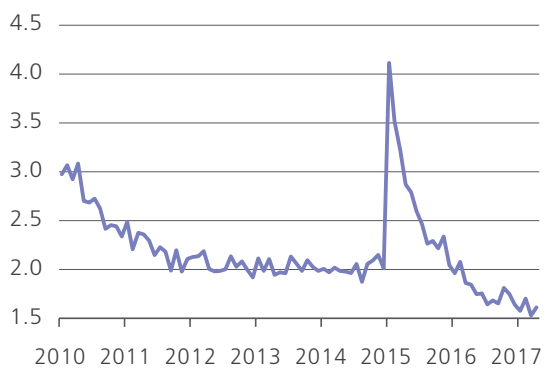

Figure 12. Standard deviation of rates on corporate loans, p.p.

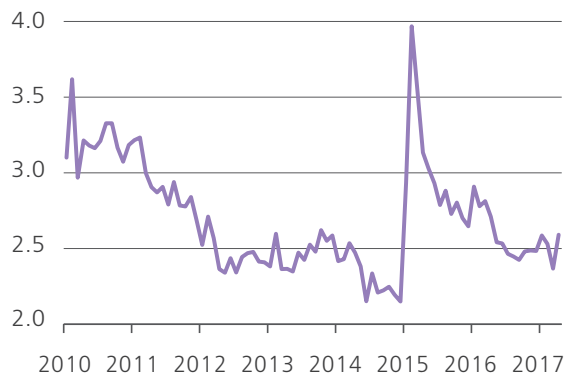

Figure 14. Standard deviation of rates on retail deposits, p.p.

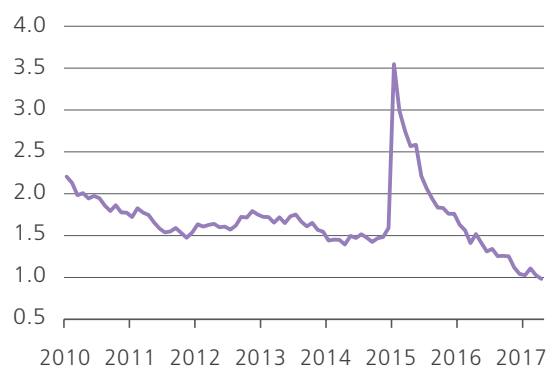

Source: authors' estimates 
of banking operations. But in this case, to eliminate nonrelevant observations, we concentrated analysis on 600 banks ordered by size.

However, the conclusion about a probable significant impact of the Bank of Russia's proactive banking sector recovery policy on the competition indicator performance only held for the retail lending segment. As regards the standard deviation of rates in this segment, the Andrews test showed a structural break in February 2015 (supF-test $=7.57$, p-value $=0.08$ ) (Figure 43, Appendix 5), which was no longer detected after a dummy variable for the Bank's of Russia proactive supervision policy was included in the model.

In the other segments, a structural break in the performance of competition indicator measured by the standard deviation of rates adjusted for risk, bank size and the macroeconomic environment identified by the Andrews test in the first step (Figures 44 - 46, Appendix 5) was detected by tests also after the Bank of Russia's proactive supervision policy was controlled for.

Thus, the comprehensive analysis of various indicators of dispersion of rates adjusted for risk and macroeconomic factors suggests possible competition strengthening in the main banking segments. Still, we cannot claim that competition strengthening is due to proactive supervision policy by the Bank of Russia. The significance of this factor proves to be nonrobust to competition assessment method.

\subsubsection{The rate spread and its difference between large and small banks.}

Both indicators of the rate spread difference show a downward trend in the last years of the period under study, coinciding with the time of the Bank of Russia's proactive supervision policy (Figure 15, Figure 16).

A formal test for a structural break points to a structural break for the rate spread difference between the largest and smallest banks in the corporate segment in November 2015 ( supF test $=9.06$, p-value $=0.04)($ Figure 47, Appendix 6). At the same time, after control for the Bank of Russia's proactive supervision policy, the test identifies a break earlier, in January 2012 (

Figure 15. Spread of rates in the corporate segment, p.p.

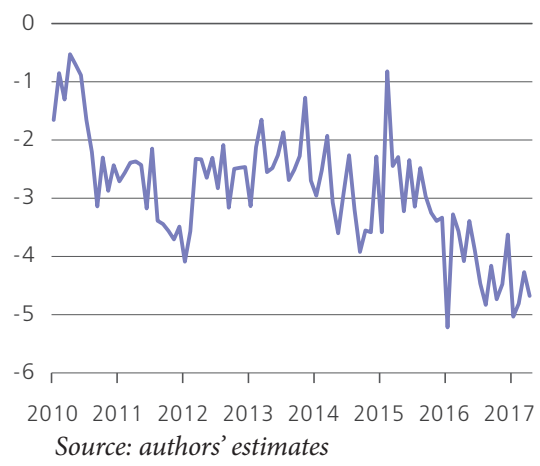

Figure 16. Spread of rates in the retail segment, p.p.

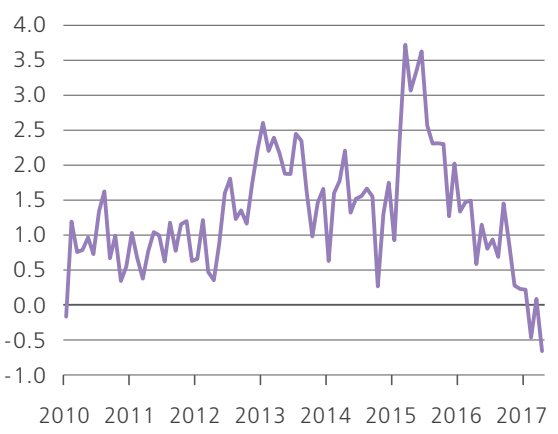


the enhancement of banking system recovery policy by the Bank of Russia (Figure 48, Appendix 6). This probably suggests a significant impact of active banking sector supervision policy on competition trends in the banking sector. However, this is not the only factor which may cause a competition rise in the corporate segment.

In the retail segment, a test for a structural break identifies a break in February 2016 (supF-test $=30.23$, p-value $=0.000)($ Figure 49, Appendix 6), which persists after the Bank of Russia's banking sector recovery policy is controlled for (Figure 50, Appendix 6). Therefore, a significant break in competition performance in the retail segment which most likely signals competition strengthening in the sector, probably was not owed to proactive supervision policy pursued by the Bank of Russia.

\subsection{Testing results: a more complex competition measure}

We have also considered other competition measures used in the literature on the banking sector and in studies dealing with the measures of competition in the Russian banking sector.

We have computed the Boone indicator, estimating two versions of the Boone indicator for the corporate and retail segments. In both cases, we used ROA and a bank's share in the relevant loan market as the dependent variable.

$$
\begin{gathered}
\log \left(R O A_{i t}\right)=\alpha+\sum_{t} \beta_{t} * \log \left(M C_{i t}\right)+u_{i t} \\
\log \left(\text { market share }_{i t}\right)=\alpha+\sum_{t} \beta_{t} * \log \left(M C_{i t}\right)+u_{i t}
\end{gathered}
$$

To compute the marginal costs we estimated the derivative of the Russian banks' costs specified in the translogarithmic form in accordance with Leuvensteijn (2008):

$$
\begin{gathered}
\log \left(T C_{i t}\right)=\alpha_{0}+\sum_{j} \beta_{j} \log X_{i j t}+\sum_{j} \sum_{k} \gamma_{j k} \log X_{i j t} \log X_{i k t}+\sum_{t} \delta_{t} d_{t}+u_{i t} \\
M C_{i t}^{l}=\frac{\partial T C_{i t}}{\partial X_{i t}{ }^{l}}
\end{gathered}
$$

for $i$-bank in quarter $t$ :

$l$ - corporate or retail loans, $d_{t}$ - fixed time effects, $u_{i t}$ - regression error, $X_{i t}-$ one of the explanatory variables out of three factor groups:

1) bank output: corporate and retail loans, investments in securities and other services (a proxy - a bank's noninterest income);

2) input prices: personnel expenses, deposit/funding price;

3) control variables: share of capital in a bank's liabilities. 
Table 2. Specification of cost function estimated

\begin{tabular}{|c|c|c|}
\hline Variable & Coefficient & $\begin{array}{l}\text { Standard } \\
\text { error }\end{array}$ \\
\hline Intercept (Constant term) & $-5.07^{\star * *}$ & 1.09 \\
\hline $\log$ (share of household loans in bank assets) & $0.79^{\star * *}$ & 0.13 \\
\hline $\log$ (share of corporate loans in bank assets) & -0.08 & 0.22 \\
\hline $\log$ (share of securities in bank assets) & $-0.01^{\star *}$ & 0.00 \\
\hline $\log$ (share of noninterest income in bank income) & $1.86^{\star * *}$ & 0.25 \\
\hline $\log$ (share of labor cost in bank assets) & $1.48^{* * *}$ & 0.56 \\
\hline $\log$ (interest expenses as a percentage of a bank's debt) & -0.04 & 0.06 \\
\hline $\log$ (share of capital in bank liabilities) & $-0.95^{* * *}$ & 0.32 \\
\hline $\begin{array}{l}\log \text { (share of household loans in assets }) \times \log \text { (share of nonintrest } \\
\text { income in bank income) }\end{array}$ & $-0.19^{* * *}$ & 0.03 \\
\hline $\begin{array}{l}\log \text { (share of household loans in assets) } \times \log \text { (share of labor cost } \\
\text { in assets) }\end{array}$ & 0.00 & 0.01 \\
\hline $\begin{array}{l}\log (\text { share of household loans in assets }) \times \log \text { (interest expense as } \\
\text { a percentage of debt) }\end{array}$ & -0.00 & 0.01 \\
\hline $\begin{array}{l}\log \text { (share of household loans in assets) } \times \log \text { (share of capital in } \\
\text { liabilities) }\end{array}$ & $0.02^{* *}$ & 0.01 \\
\hline $\begin{array}{l}\log \text { (share of corporate loans in assets }) \times \log \text { (share of noninterest } \\
\text { income in income) }\end{array}$ & -0.02 & 0.05 \\
\hline $\begin{array}{l}\log \text { (share of corporate loans in assets) } \times \log \text { (share of labor cost } \\
\text { in assets) }\end{array}$ & 0.02 & 0.02 \\
\hline $\begin{array}{l}\log (\text { share of corporate loans in assets) } \times \log \text { (interest expense as } \\
\text { a percentage of debt) }\end{array}$ & $0.05^{* * *}$ & 0.01 \\
\hline $\begin{array}{l}\log \text { (share of corporate loans in assets) } \times \log \text { (share of capital in } \\
\text { liabilities) }\end{array}$ & $0.07^{\star * *}$ & 0.01 \\
\hline $\begin{array}{l}\log (\text { share of labor cost in assets }) \times \log (\text { share of noninterest } \\
\text { income in income })\end{array}$ & $-0.33^{* * *}$ & 0.12 \\
\hline $\begin{array}{l}\log (\text { share of labor cost in assets }) \times \log \text { (interest expense as a } \\
\text { percentage of debt) }\end{array}$ & 0.00 & 0.02 \\
\hline $\begin{array}{l}\log (\text { share of capital in bank liabilities }) \times \log \text { (share of noninterest } \\
\text { income in income) }\end{array}$ & $0.16^{* *}$ & 0.07 \\
\hline $\begin{array}{l}\log (\text { share of capital in liabilities }) \times \log \text { (interest expense as a } \\
\text { percentage of debt) }\end{array}$ & 0.00 & 0.02 \\
\hline Number of observations / banks & \multicolumn{2}{|c|}{$11,869 / 772$} \\
\hline $\mathrm{R}^{2}$ & \multicolumn{2}{|c|}{0.837} \\
\hline $\mathrm{R}^{2}$ - adjusted & \multicolumn{2}{|c|}{0.825} \\
\hline J-test & \multicolumn{2}{|c|}{$3.60 \mathrm{E}-11$} \\
\hline
\end{tabular}

Note: The estimation was performed by the generalized method of moments with fixed individual and time effects. Estimates of coefficients before dummy variables are not shown for space considerations. $* * *, * * *$ - the estimate is significant at $1 \%, 5 \%$ and $10 \%$ level, respectively. 
Figure 17. Boone indicator in the corporate loan segment

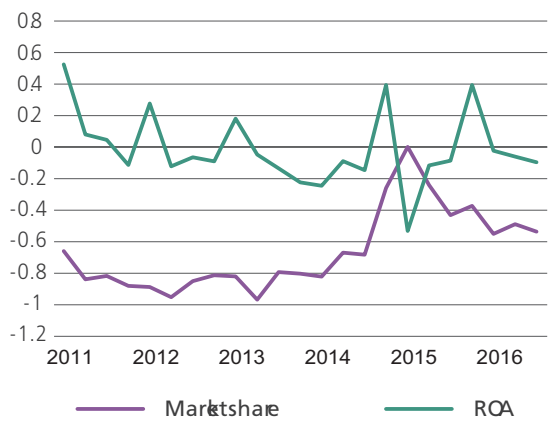

Source: authors' estimates
Figure 18. Boone indicator in the retail loan segment

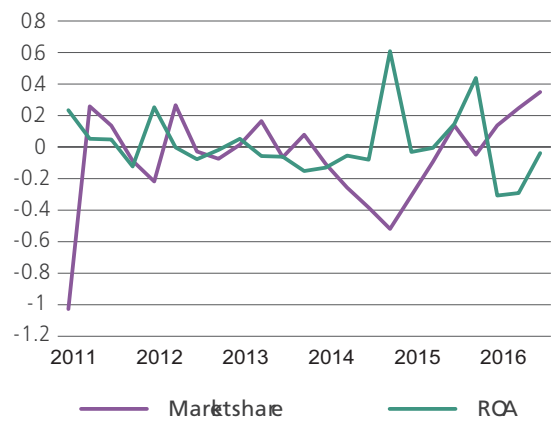

We then estimated marginal costs in each of the lending segments by taking a derivative with respect to the relevant variable which acted as a regressor in the equation for computing the Boone indicator.

The Boone indicator performance for both corporate and household loans points to the lack of a pronounced competition strengthening trend in these banking segments (Figure 17, Figure 18). As the Boone indicator was estimated using quarterly data, the number of observations available do not secure robust results while performing Andrews test for a structural break.

Table 3. Correlation analysis in the corporate loan segment

\begin{tabular}{l|c|c|c} 
& $\begin{array}{c}\text { Rate dispersion } \\
(\text { max. }- \text { min. })\end{array}$ & Rate spread & $\begin{array}{c}\text { Boone indicator } \\
\text { (market share / ROA) }\end{array}$ \\
\hline Rate dispersion (max. - min.) & 1 & 1 \\
\hline Rate spread & -0.14 & $-0.33 /-0.1$ & 1 \\
\hline $\begin{array}{l}\text { Boone indicator (market } \\
\text { share / ROA) }\end{array}$ & $0.5 / 0.16$ & -11 \\
\hline
\end{tabular}

A comprehensive analysis of competition indicators suggests a lack of correlation between indicators in the retail loan segment and a weak correlation in the corporate loan segment (Table 3, Table 4).

Hence various competition measures do not support the hypothesis of competition weakening in the Russian banking sector after the Bank of Russia had started to pursue proactive supervision policy, as follows from the analysis of structural competition measures (the Herfindahl - Hirschman index). This result is robust to various samples and competition indicators. Hence we have obtained no evidence of competition weakening in the short term as suggested by Ponomarenko 
Table 4. Correlation analysis in the retail loan segment

\begin{tabular}{l|c|c|c|} 
& $\begin{array}{c}\text { Rate dispersion } \\
(\mathbf{m a x}-\mathbf{m i n})\end{array}$ & $\begin{array}{c}\text { Rate spread } \\
\text { (market share / } \\
\text { ROA) }\end{array}$ \\
\hline Rate dispersion (max. - min.) & 1 & 1 \\
\hline Rate spread & 0.68 & \\
\hline $\begin{array}{l}\text { Boone indicator (market } \\
\text { share / ROA) }\end{array}$ & $0.03 /-0.09$ & $0.04 /-0.03$ & 1 \\
\hline
\end{tabular}

and Sinyakov (2018) ${ }^{14}$ in their study. On the contrary, the rate dispersion indicators point to gradual competition strengthening in the banking sector's main segments. The detected breaks in the pattern of competition measured by the rate dispersion indicators most probably stem from a macroeconomic shock rather than from the enhancement of supervision policy by the Bank of Russia. Still, our results do not allow ruling out the hypothesis that the impact of banking sector recovery policy on the competition trend makes itself felt gradually, impeding the identification of its effects.

\section{Measuring lending stability}

We use a structural indicator - the share of banks showing a stable lending growth rate as a measure of stability (BSS - banking sector stability):

$$
\text { BSS }_{\mathrm{t}}=\frac{\text { Number }^{15} \text { of banks showing stable growth }}{\mathrm{t}}
$$

where $t$ is a month.

We believe that a bank shows a stable lending growth rate if its volatility is below or equal to the systemic volatility. ${ }^{16}$ We assume that banks demonstrating a more unstable growth accumulate excessive risks, thereby contributing to an

\footnotetext{
14 The study by Ponomarenko and Sinyakov (2018) suggests, as part of a theoretical model, that while banking sector recovery policy has an overall positive effect on banking system efficiency and stability, it may entail a short-term competition weakening, which, under certain circumstances, may affect banking sector stability.

${ }^{15}$ Weighted by bank size.

${ }^{16}$ Individual indicator of growth rate sustainability ${ }_{i t}=$ Annual volatility of lending growth rate $_{\text {it }}$ $=$ Annual volatility of the banking system's loan portfolio growth rate where $i$ is a bank, $t$ is a month.

If the above ratio is less than one then the bank is more stable than the system as a whole, if it is equal to one, then it is as stable as the system, if it is greater than one, the bank is "no more stable" than the system as a whole. Adjustment for systemic volatility enables the individual volatility of lending growth to be adjusted for the influence of systematic factors (a business cycle, the oil price, regulatory changes, etc.) obtaining specific (idiosyncratic) volatility.
} 
Figure 19. Distribution of individual stability indicators for corporate loan portfolio prior to and after the policy launch

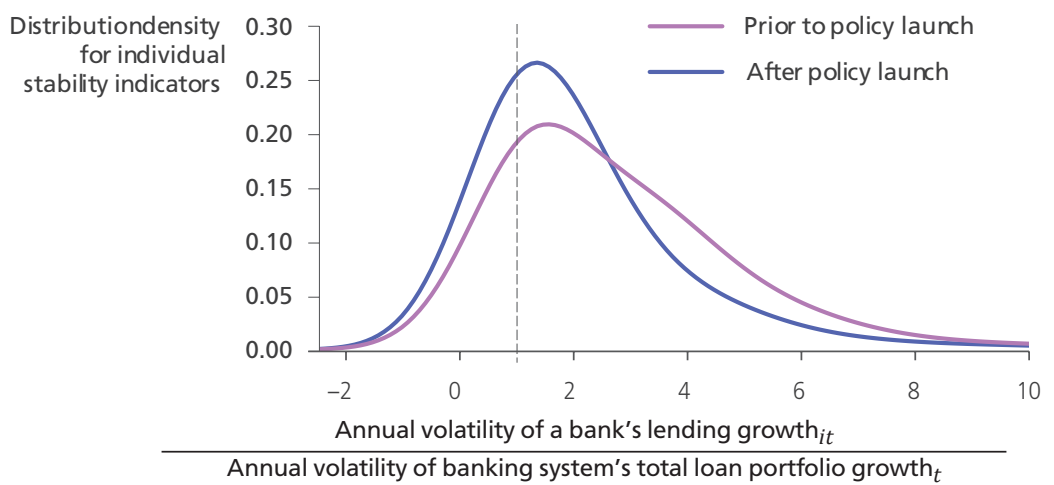

Note: The figure presents the density distribution for the ratios of annual volatility of a bank's monthly loan portfolio growth to the annual volatility of the banking system's total lending monthly growth. Movement to the left of 1 signals stability growth. The area under the curve to the left of 1 is the banking sector stability indicator (BSS). In Figure 19, the area under the blue curve (after the policy launch) up to 1 equals 0.301 , the area under the red curve (prior to the policy launch) up to 1 equals 0.213 .

Source: authors' estimates

instability rise in the banking system and lending (Rey, Excessive Credit Growth, 2015). By contrast, banks showing a more stable loan portfolio growth help a more stable expansion of lending to the economy.

To analyze the effect of banking sector recovery policy on the banking system, the BSS performance was split into that in the "prior-to-policy" and "after-thepolicy-launch" periods, which were then compared. In mathematical terms, this means that we compared empirical distributions of individual stability indicators.

\subsection{Stability trends in Russia's banking sector}

The empirical distribution of individual growth stability indicators and BSS showed the convergence of growth rates for both the retail and corporate loan portfolios, in the period following the launch of banking sector recovery policy (Figure 19, Figure 20). So far, the effect is more pronounced in the corporate lending segment. We estimate that the systemic stability indicator ${ }^{17}$ increased by $3.7 \%$ in the retail lending segment and $41 \%$ in that of corporate lending. Similar estimation on a subsample of regional banks indicated a more significant stability

\footnotetext{
${ }^{17}$ The system stability indicator is defined as follows:

1) Individual stability is related to system stability, and if this ratio is less than one, the bank is more "stable" than the system as a whole, if it is equal to one, then it is as stable as the system, if it is greater than one, then the bank is "no more stable" than the system as a whole. The vertical line in Figure 19 shows the systematic stability level.

2) The system stability is equal to the sum of individual stability indicators which are less than one, i.e., located in the area to the left of the vertical line in Figure 19.
} 
Figure 20. Distribution of individual stability indicators for the retail loan portfolio prior to and after policy launch

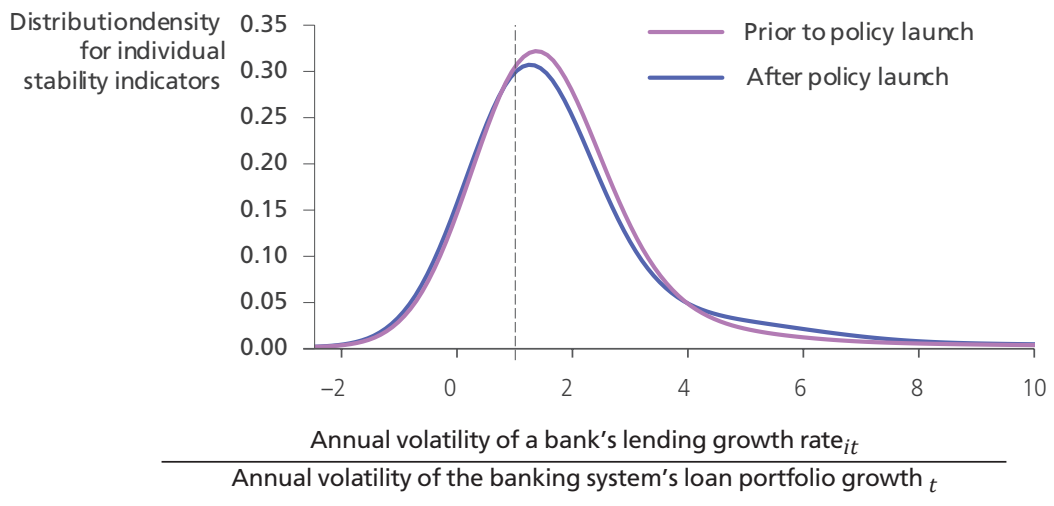

Note: The figure presents the density distribution for the ratios of annual volatility of a bank's monthly loan portfolio growth to the annual volatility of the banking system's total retail lending monthly growth. Movement to the left of 1 signals stability growth. The area under the curve to the left of 1 is the systematic stability indicator. In Figure 20, the area under the blue curve (after the policy launch) up to 1 equals 0.331 , the area under the red curve (prior to the policy launch) up to 1 equals 0.319 .

Source: authors' estimates

rise. The systemic stability indicator went up $29 \%$ in the retail lending segment and $41 \%$ in that of corporate lending.

To get an insight into what the sources of BSS improvement are, we have performed cluster analysis. In doing so, clustering for both the corporate and retail loan portfolio was performed with respect to the share of the relevant loan portfolio in a bank's assets and the level of nonperforming loans in it. In both cases, the k-means method was used. We chose three clusters based on the need for reasonable economic interpretation of each cluster obtained and minimization of the sum of error squares.

In both cases we obtained the following bank clusters:

- "Banks showing successful specialization" - banks with a relatively high share of retail/corporate loans in their assets and a relatively low share of nonperforming loans (Cluster 1 in Figures 21-24).

- "Banks showing successful nonspecialization" - banks with a relatively low share of retail/corporate loans in their assets and a relatively low share of nonperforming loans (Cluster 2 in Figures 21-24).

- "High-risk banks" - banks with a relatively low share of retail/corporate loans in their assets and a relatively high share of nonperforming loans (Cluster 3 in Figures 21-24).

In Appendices 3 and 4, distribution densities of individual growth rate indicators for all he clusters of corporate and retail lending are presented. Note that the convergence of loan portfolio growth rates is above all indicated in the 
Figure 21. Bank clusters in retail lending (normalized indicators)

\begin{tabular}{c|c|c|c} 
Cluster & $\begin{array}{c}\text { Share of loan portfolio in } \\
\text { assets, p.p. }\end{array}$ & $\begin{array}{c}\text { Level of nonperforming } \\
\text { loans, p.p. }\end{array}$ & Number of banks \\
\hline 1 & 1.9 & -0.3 & 149 \\
\hline 2 & -0.3 & -0.3 & 701 \\
\hline 3 & -0.5 & 2.3 & 104 \\
\hline
\end{tabular}

Figure 22. Bank clusters in retail lending

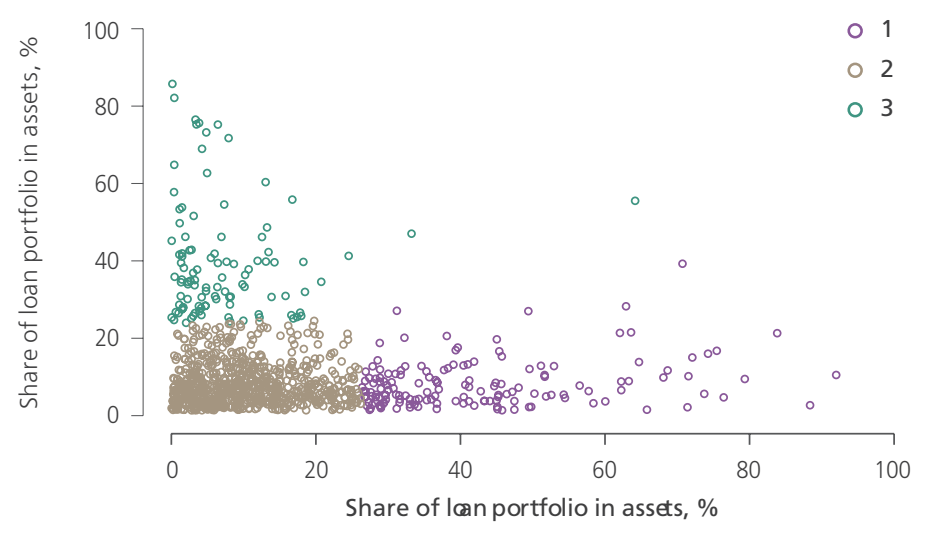

Figure 23. Bank clusters in corporate lending (normalized indicators)

\begin{tabular}{c|c|c|c} 
Cluster & $\begin{array}{c}\text { Share of loan portfolio in } \\
\text { assets, } \mathbf{p} \cdot \mathbf{p} .\end{array}$ & $\begin{array}{c}\text { Share of loan portfolio } \\
\text { in assets, } \mathbf{p . p} .\end{array}$ & Number of banks \\
\hline 1 & 0.8 & -0.3 & 480 \\
\hline 2 & -0.8 & -0.1 & 415 \\
\hline 3 & -0.4 & 3.0 & 67 \\
\hline
\end{tabular}

Figure 24. Bank clusters in corporate lending

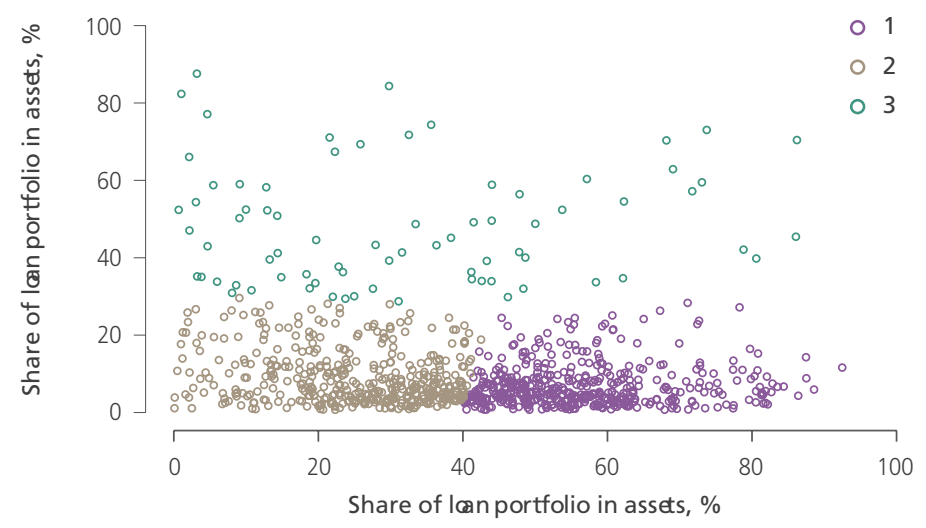

Source: authors' estimates 
clusters showing a relatively low share of non-performing loans in both corporate and retail lending. At the same time, the cluster of banks with a relatively high share of nonperforming loans shows a division of banks into those which demonstrated more stable lending growth after the start of proactive supervision policy and those whose loan portfolio growth volatility remained high, because of, among other things, the bank size. ${ }^{18}$

However, from the perspective of financial stability, it is not so much a riskprofile of each bank as similarity of banks' risk management policies that counts the notion of systemic risk. A systemic risk indicator used in Leroy and Lucotte (2017) is SRISK (Acharya et al., 2012), Brownlees and Engle (forthcoming)

Figure 25. SRISK, normalized by the financial system's assets

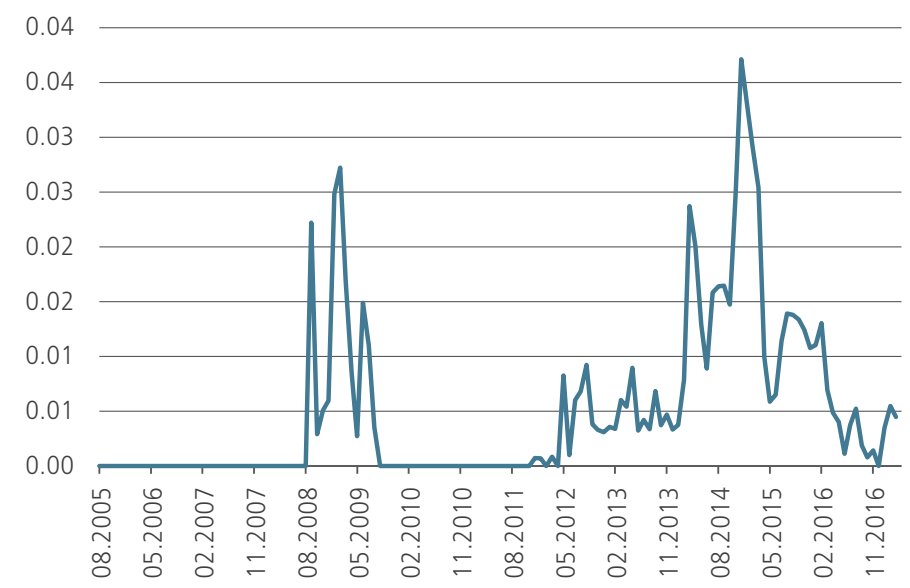

Source: The Volatility Institute.

assessing systemically important organizations' requirement of capital in the event of a systemic financial crisis. For Russia, this index points to a systemic risk decline after its considerable rise in late 2014 (Figure 25).

We note that a proxy for stability that empirical studies most often use is Z-index under Roy's methodology (Roy, 1952). The index is usually thought of as showing "a distance to default", because it measures by how many standard deviations a bank's profitability should drop for its losses to exceed its capital (Boyd et al., 2006; Uhde and Heimeshoff, 2009; Turk-Ariss, 2010):

$$
Z_{i t}=\frac{\frac{E_{i t}}{A_{i t}}+\overline{R O A_{i t}}}{\sigma_{R O A_{i t}}}
$$

where $i$ is a bank, $t$ is a month, ROA is return on assets, $E / A$ is the equity-toto assets ratio, $\sigma_{R O A}$ is standard deviation of ROA.

\footnotetext{
${ }^{18}$ Empirical distribution was constructed based on the individual stability indicators weighted by bank size.
} 
For the Russian banking sector, this performance of the Z-index suggests possible risk decline after a significant rise in their vulnerability in the period of financial shocks (Figure 26). These changes in the indicator are in line with the gradual increase in the banking sector's stability at the end of the period concerned.

Figure 26. Z-index dynamics of Russia's banking sector

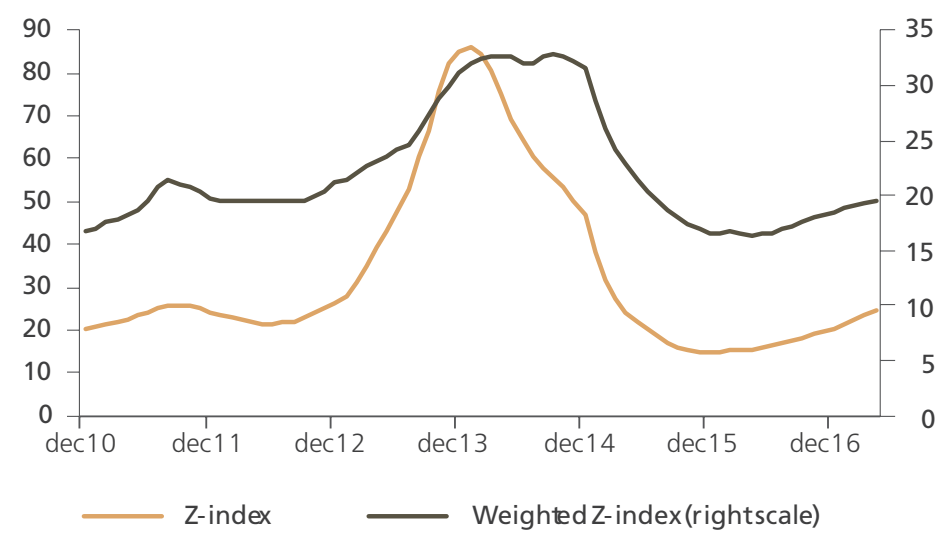

Source: authors' estimates

\section{Conclusion}

We have estimated several competition indicators to examine the level of competition in Russia's banking sector prior to and after supervision policy enhancement by the Bank of Russia. Analysis of their performance suggests possible competition strengthening in the retail banking segment after policy was stepped up. All the indicators examined point to this trend, with the only exception of the Boone indicator which remained unchanged throughout the period under study. However, we cannot draw a definitive conclusion about the dynamics of competition processes in the corporate segment because there is no correlation between various indicators. Thus, the competition measures examined do not support the hypothesis of competition weakening in the Russian banking sector after the launch of proactive supervision policy by the Bank of Russia, as follows from the analysis of just structural competition measures (the Herfindahl Hirschman index).

Structural breaks were detected in the performance of competition measures in the period following the Bank of Russia's supervision policy enhancement. They cannot however be unambiguously associated with the regulator's proactive supervision policy, as the significance of the impact of this factor does not prove to be robust to the competition assessment method. This may in part be due to the fact that the impact of banking sector recovery policy on the competition trends makes itself felt gradually, impeding the identification of its effects. We therefore cannot claim that possible competition strengthening is owed to the Bank of Russia's proactive supervision policy. 
We have also assessed the Russian banking sector stability. The period after the launch of policy saw a decline in the volatility of corporate and retail lending both in the cluster of banks showing a relatively low level of nonperforming loans and, to a certain extent, among banks with a relatively high NPL level. Therefore, the regulator's banking sector recovery policy probably had no significant negative effect on competition in the period under study, while the volatility of lending growth rate declined, accompanied by relatively low values of the systemic risk indicator SRISK and gradual recovery of the Z-index, in line with the rising banking sector stability.

Appendices are available at www.cbr.ru/money-and-finance

\section{References}

Anisimova, A. and Vernikov, A. (2011). Structure of the banking services market and its influence on competition: the case of two Russian regions. Dengi i Kredit, 11, 53-62 (in Russian).

Allen, F. and Gale, D. (2004). Competition and financial stability. Journal of Money, Credit and Banking, 36(3), pp. 453-480.

Acharya, V., Engle, R. and Richardson, M. (2012). Capital shortfall: a new approach to ranking and regulating systemic risks. American Economic Review, 102 (3), pp. 59-64.

Andrews, D. (1993). Tests for parametric instability and structural change with unknown change point. Econometrica, 61, pp. 821-856.

Beck, T. (2008). Bank competition and Financial stability: Friends or Foes? World Bank. Available at: siteresources.worldbank.org/INTFR/Resources/BeckBankCompetitiona ndFinancialStability.pdf

BIS (2018). Structural changes in banking after the crisis. Commitee on the Global Financial System Papers, №60.

Boone, J. (2008). A new way to measure competition. Economic Journal, vol. 118, issue 531, pp. 1245-1261.

Boyd, J., De Nicolo, G. and Smith, B. (2004). Crises in competitive versus monopolistic banking systems. Journal of Money, Credit and Banking, 35, pp. 487-506.

Boyd, J. and De Nicolo, G. (2005). The theory of bank risk taking and competition revisited. Journal of Finance, Vol. 60, issue 3, pp. 1329-1343.

Brownlees, C. and Engle, R. (forthcoming). SRISK: a conditional capital shortfall measure of systemic risk. Review of Financial Studies.

Carbó, S., Hamphrey, D., Maudos, J. and Molyneux, P. (2009) Cross-country comparisons of competition and pricing power in European banking. Journal of International Money and Finance, 28 (1), pp. 115-134.

Claessens, S. and Laeven, L. (2004). What drives bank competition? Some international evidence. World Bank Policy Research Working Paper № 3113.

de Guevara, F. and Maudos, J. (2004). Factors explaining the interest margin in the banking sectors of the European Union. Journal of Banking and Finance, 28(9), pp. 2259-2281. 
de Guevara, F., Maudos, J. and Pérez, F. (2007). Integration and competition in the European financial markets. Journal of International Money and Finance, 26(1), pp. 26-45.

Demsetz, H. (1973). Industry structure, market rivalry and public policy. Journal of Law and Economics, 16, pp. 1-9.

Drobyshevsky, S. and Paschenko, S. (2006) An analysis of competition in the Russian banking sector. Proceedings of IEPP. 2006. - № 96. - 130: ISBN 5-93255-196-8 (in Russian).

Florian, L. (2015). Measuring competition in banking: a critical review of methods. Available at: https://hal.archives-ouvertes.fr/halshs-01015794/document

Fuller, W. (1996). Introduction to statistical time series. 2d ed. New York: Wiley.

Fungáčová, Z. and Weill, L. (2013). Does competition influence bank failures: evidence from Russia. Economics of Transition, Vol. 21, issue 2, pp. 301-322.

Fungacova, Z., Solanko, L. and Weill, L. (2010). Market power in the Russian Banking industry. Working paper 2010-09.

Gerardi, K. and Shapiro, A. (2009). Does competition reduce price dispersion? New evidence from the Airline Industry. Journal of Political Economy, Vol. 117, No. 1, pp. 1-37.

Lach, S. (2002). Existence and persistence of price dispersion: An empirical analysis. The Review of Economics and Statistics, 84(3), pp. 433-444. Retrieved from http:// www.jstor.org/stable/3211562

Lerner, A. (1934). The concept of monopoly and the measurement of monopoly power. Review of Economic Studies, Vol. 1, issue 3, pp. 157-175.

Leroy, A. and Lucotte, Y. (2017). Is there a competition stability trade-off in European banking? Journal of International Financial Markets, Institutions and Money, 46, pp. 199-215.

Leuvensteijn, M., Sorensen, C., Bikker, J. and Rixtel, A. (2008). Impact of bank competition on the interest rate pass-through in the euro area. Working Paper Series 885, European Central Bank.

Mamonov, M. (2016). Competition in the Russian lending market: influence on the banks' lending activity and assessment of the impact of the 2008-2009 economic crisis. Voprosy Ekonomiki, 11, pp. 76-99 (in Russian).

Martinez-Miera, D. and Repullo, R. (2010). Does competition reduce the risk of bank failure? The Review of Financial Studies, 23(10), pp. 3638-3664.

Mason, E. (1939). Price and production policies of large-scale enterprise. American Economic Review, 29, pp. 61-74.

Matutes, C. and Vives, X. (2000). Imperfect competition, risk taking and regulation in banking. European Economic Review, Vol. 44, issue 1, pp. 1-34.

Orlov, E. (2011). How does the internet influence price dispersion? Evidence from the airline industry. The Journal of Industrial Economics, 59(1), pp. 21-37.

Panzar, J. and Rosse, J. (1987). Testing for monopoly equilibrium. Journal of Industrial Economics, vol. 35, issue 4, pp. 443-56.

Phillips, P. and Perron, P. (1998). Testing for a unit root in time series regression. Biometrica, 75 (2), pp. 335-346. 
Ponomarenko, A., Sinyakov, A. (2018). Impact of banking supervision on banking system structure: Conclusions from agent-based modeling. Russian Journal of Money and Finance, 77 (1), pp. 26-50.

Reinhart, C. and Rogoff, K. (2010). Growth in a time of Debt. American Economic Review, 100 (2), pp. 573-78.

Rey, H. (2015). Dilemma not trilemma: The global financial cycle and monetary policy independence. NBER Working paper 21162.

Available at: www.nber.org/papers/w21162.

Robinson, J. (1933). The economics of imperfect competition. London: Macmillan.

Ross, S. (1976). The arbitrage theory of capital asset pricing. Journal of Economic Theory, 13, pp. 341-360.

Roy, A. (1952). Safety first and the holding of assets. Econometrica, 20(3), pp. 431-449.

Salop, S. and Stiglitz, J. (1977). Bargains and ripoffs: A Model of monopolistically competitive price dispersion. The Review of Economic Studies, 44(3).

Schaeck, K. and Cihak, M. (2014). Competition, efficiency and stability in banking. Financial Management, Vol. 43, issue 1, pp. 215-241.

Shaffer, S. (1982). A nonstructural test for competition in financial markets. In: Federal Reserve Bank of Chicago. Proceedings of a conference on bank structure and competition, pp. 225-243.

Smith, B. (1984). Private information, deposit interest rates, and the stability of the banking system. Journal of Monetary Economics, Vol. 14, issue 3, pp. 293-317.

Turk-Ariss, R. (2010). On the implications of market power in banking: evidence from developing countries. Journal of Banking and Finance, Vol. 34, issue 4, pp. 765-775.

Uhde, A. and Heimeshoff, U. (2009). Consolidation in banking and financial stability in Europe: empirical evidence. Journal of Banking and Finance, Vol. 33, issue 7, pp. 1299-1311.

Vernikov, A. (2013). National champions in the structure of Russia’s banking services market Russian banking industry. Voprosy Ekonomiki, 3, pp. 94-108 (in Russian).

Vives, X. (2016). Competition and stability inbanking: The Role of regulation and competition policy. Princeton, Oxford: Princeton University Press, 2016. 